\title{
MATHEMATICAL MODEL OF EMISSION TOXIC COMPOUNDS IN EXHAUST GASES FROM TANKERS NAVIGATING TO LIQUID FUEL TERMINAL IN PORT OF GDANSK
}

\author{
Tomasz Kniaziewicz, Leszek Piaseczny \\ Polish Naval Academy \\ Faculty of Mechanical and Electrical Engineering \\ Smidowicza Street 69, 81-103 Gdynia, Poland \\ tel.: +48586262851, 262681 \\ e-mail:t.kniaziewicz@amw.gdynia.pl,piaseczny@ptnss.pl
}

\begin{abstract}
The current worldwide research on atmospheric pollution caused by emission of toxic compounds from marine engines is based on a simplified input data. Existing databases of emission of toxic compounds in exhaust gases of vessels navigating in various parts of the world could not be used to estimate the emissions in the meso and micro scale such as the Baltic Sea or the Bay of Gdansk, because it leads to over-generalization of emission indicators, mainly due to lack of required detailed traffic characteristics.

The article presents the methodology of identifying the marine engine load to determine the indicators and characteristics of the emission of toxic compounds in the exhaust gases from tankers navigating to the Liquid Fuel Terminal in Gdansk.

Course of action presented for modelling the characteristics of toxic emission of marine Diesel engines of main propulsion. It the range of indispensable analytic works will be describe to defining on basis on ships' resistor profiles, the profiles of load, helical, speed of navigation based on the parameters of movement ship gain over with system AIS.
\end{abstract}

Keywords: modelling, emission, ships, engine, AIS

\section{Introduction}

In modelling characteristics of pollution emission by marine Diesel engines, what is of key importance is the identification of true conditions of the vessel's operating and on this basis working out the characteristics of the ship's movement system, which as a rule are a set of functional connections of particular hull and propulsion system parameters [6].

The ecological characteristics of marine diesel engines generally apply to emissions of nitrogen oxides, carbon monoxide and hydrocarbons to the atmosphere in the ship's real sailing condition. One of the many forms of ecological characteristics of the marine engines is the dependence of $E_{Z T}$ $=P_{e} \cdot e_{Z T}$ under specific external conditions $Z=i d e m$, where $E_{Z T}$ is the intensity of emission of toxic compounds, effective engine power $P_{e}, e_{Z T}$ unit emissions of toxic compounds.

Process of modelling the emission of toxic compounds in the exhaust gases from marine Diesel engines consists of five steps [4]:

- Phase 1 - creating a statistical database of traffic under normal operating conditions of the analyzed vessels ( $v_{n}$ rated velocity and maximum velocity $v_{\max }$ ), the main dimensions of hull $(L, B, T)$, general data of the installed engines of main propulsion (the number and type of engines - two-stroke, four-stroke, nominal and maximum power values and of the engine's rotational speed $\left.P_{e(n)}, n_{n}, P_{e(\max )}, n_{\max }\right)$. Among basic data there also the values of observed movement speed $v$ in real external conditions of sailing,

- Phase 2 - determining the general resistance characteristic, which takes into consideration the actual external conditions (proximal and distal) having the significant impact on the condition of work of propulsion system and the emission of toxic compounds in the exhaust gas, 
- Phase 3 - examining and determining the general propeller characteristics of the main engine power related to the engine's rotational speed and speed of the vessel,

- Phase 4 - developing a general propeller characteristic of emission the basic toxic compounds (e.g. nitrogen oxides $N O_{x}$, carbon monoxide $C O$ and hydrocarbons $H C$ ). This task requires a fairly extensive experimental research of engine in the laboratory conditions and routine operational conditions,

- Phase 5 - determining (in accordance with ISO 8178) the parameters of emission, depending on the operating conditions of marine engines in the form of complete ecological characteristics.

\section{Methods of identifying the main propulsion engine load of vessels in order to evaluate the emissions of toxic compounds in the exhaust gas of tankers}

Movement of vessels navigating at sea is generally designated by communication routes $[4,5]$. Naval communication route consists of $m$ sections of the waterway, which lengths are defined by vector. Individual sections of communication route have different values of parameters of sailing area $\bar{p}_{i}=\left(p_{i 1}, p_{i 2}, \ldots\right)$, which significantly affect on the operation of the vessel propulsion system. This means that the basic quantity characterizing the ship's movement system, which is the hull resistance $R_{i}=\left(v_{i}, \bar{p}_{i}\right)$ on the $\mathrm{i}$-th fairway section of length $r_{i}$ depends on the parameters $\bar{p}_{i}$ and the vessel's speed $v_{i}$.

On the particular sections of water track, the velocity of vessel is described by the vector $\bar{v}=\left(v_{1}, v_{2}, \ldots, v_{m}\right)$. Velocity of vessel depends also on the value and parameters of the hull $\bar{p}_{i}=\left(p_{i 1}, p_{i 2}, \ldots\right)$. Vector describes the parameters of the different sections of waterway, taking into account the external sailing conditions and parameters of the hull and propulsion system of the vessel. In the description is established following $\bar{p}_{i}=\left(p_{i 1}, p_{i 2}, \ldots\right)$, where:

- $p_{i l}=h_{i} / T$ - the ratio of the depth of the i-th waterway section to the vessel's draft,

$-p_{i 3}=v_{w i}-$ wind speed at the i-th fairway section,

$-\quad p_{i 3}=c_{f}-$ hull roughness.

There are also constant parameters characterizing vessels on specific sections of the waterway issued by the AIS System and corresponding to published data sheets, and also established values of the selected parameters that were included in the database. For this type of parameters are:

- $p 4=L-$ hull length,

- $p 5=B-$ hull breadth,

- $p 6=T-$ hull draft,

- $p 7=\delta-$ hull block coefficient,

- $p 8=P e(n)$ - effective installed power (nominal) in the propulsion system,

- $\quad p 9=v n-v e s s e l$ 's nominal speed.

\subsection{Resistive characteristics of watercraft}

On the basis of the achievements in the field of theoretical modelling, we can assume that the theoretical total resistance of the vessel can be expressed using the approximate relationship [7-9]

$$
R_{t}=R_{w}+R_{v}+R_{p}=\frac{1}{2}\left[C_{w} \cdot(\bar{K}, F r)+C_{v} \cdot(\bar{K}, R n)+C_{p}\right] \cdot \rho \cdot v^{2} \cdot \Omega(\bar{K}),
$$

where:

$R_{w}=C_{w}(\bar{K}, F r) \cdot \rho \cdot v^{2} \cdot \Omega(\bar{K})-$ wave resistance of the vessel, 
$C_{w}-$ dimensionless coefficient of resistance is a function, which is depend on the shape of the hull expressed by the set of shape parameters $K=\left(p_{1}, p_{2}, \ldots, p_{n}\right)$ and the Froude number $F n=\frac{v}{\sqrt{L \cdot g}}$,

$R_{v}=C_{v}(\bar{K}, R n) \cdot \rho \cdot v^{2} \cdot \Omega(\bar{K})-$ viscosity resistance,

$C_{v} \quad-$ dimensionless resistance coefficient depends on the shape of the hull and the Reynolds number $R n=\frac{v \cdot L}{\mu / \rho}$,

$v \quad-$ vessel velocity,

$L \quad-$ hull's length,

$\mu \quad-$ coefficient of dynamic viscosity of water,

$\rho \quad-$ density of water,

$\Omega \quad-$ hull's moistened surface,

$R_{p}, C_{p}$ - resistance and coefficient of additional components (e.g. aerodynamic resistance, resistance after the change of roughness etc.)

However, form of expressions presented above has definitional character of the resistance and does not provide a calculation of the resistance characteristic of the vessel. Therefore modelling the resistance of the hull depending on the velocity of vessel is based only on empirical methods. Among several methods and due to the simple algorithmic structure and usefulness of the computer in coding the numerical algorithms, noteworthy is known method described in the paper [10]:

where:

$$
R=g\left\{0.17 \cdot \Omega \cdot v^{1.825}+1.45\left(24-\frac{L}{B}\right) \delta^{\frac{5}{2}} \frac{D}{L^{2}} v^{4}\right\},
$$

$g\left[\mathrm{~m} / \mathrm{s}^{2}\right]$ - acceleration of gravity,

$\Omega\left[\mathrm{m}^{2}\right] \quad$ - hull's moistened surface,

$v[\mathrm{~m} / \mathrm{s}] \quad-$ velocity of the vessel,

$B, L[\mathrm{~m}]$ - hull's breadth and length of designed waterline,

$\delta \quad-$ hull's block coefficient,

$\delta=\frac{V}{L \cdot B \cdot T}$,

$D[\mathrm{t}] \quad-$ vessel's displacement.

Figure 1 shows the general average standard characteristics of the resistance, determined on the basis of equation (2) and the data generated by the AIS System [4]. Curve presented in this figure and the corresponding approximating polynomial can be used in considering the resistance of vessels with displacement hulls at a confidence level $\alpha=0.95$ in the conventionally accepted conditions of routine operation $\left(S M \leq 3^{\circ} \mathrm{B}, h>20 \mathrm{~m}, D=D_{n}, c_{f}=c_{f(n)}\right)$.

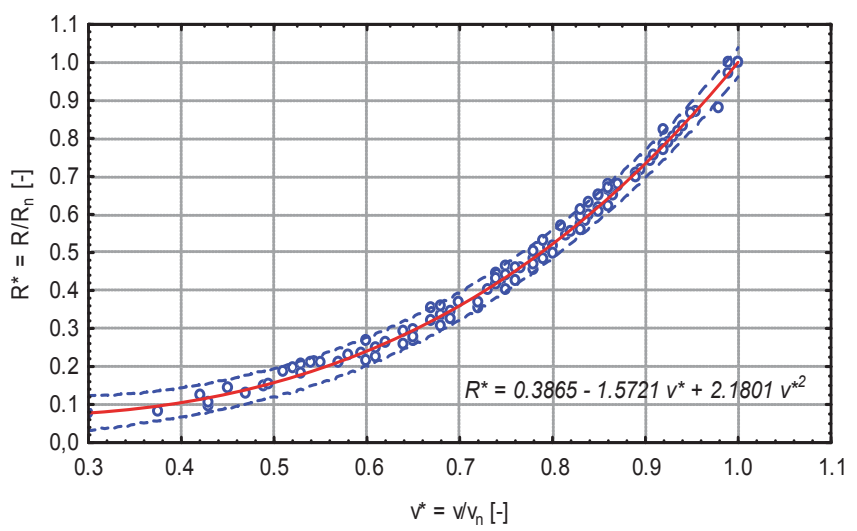

Fig. 1. General resistive characteristics of the vessels with displacement hulls [4] 
In the case of tankers, due to the way they operate, we must take into account also the change of characteristics of resistance of the hull due to the state of loading. According to the dependence of the admiralty, the change in resistance is a result of the altered state of loading of the vessel and it can be applied to the actual value of the hull draft $T$ :

$$
\frac{R_{n}}{R}=\left(\frac{T_{n}}{T}\right)^{\frac{2}{3}}
$$

where:

$R_{n}$ - resistance of the hull at nominal load of the hull,

$R$ - resistance of the hull at the current load (draft),

$T_{n}$ - draft corresponding to the nominal load,

$T$ - draft at current load of the hull.

\subsection{Characteristics of diesel engine power}

To drive the vessel at velocity $v_{i}$ on a particular section of sea route $r_{i}$ and demand power output main drive motor $P_{e(i)}$ can be expressed as the overall relationship:

$$
P_{e_{(i)}}=\frac{R\left(v_{i}, \bar{p}_{i}\right) \cdot v_{i}}{\xi_{o}\left(v_{i}, \bar{p}_{i}\right)}=\frac{R\left(v_{i}, \bar{p}_{i}\right) \cdot v_{i}}{\eta_{p}\left(v_{i}, \bar{p}_{i}\right) \cdot \xi_{k}\left(v_{i}, \bar{p}_{i}\right) \cdot \xi_{r}\left(v_{i}, \bar{p}_{i}\right)}[\mathrm{W}] .
$$

Assuming that the efficiency of propulsion $\xi_{o}$ at the range of variation of the velocity vectors $\bar{v}$ and the parameters of waterway and the hull $\bar{p}$ takes constant values, as well as the particular fairway parameters of the on a particular section not differ significantly, the relation (4) simplifies to the following form:

$$
P_{e_{(i)}} \approx \frac{R\left(v_{i}, \bar{p}_{i}\right) \cdot v_{s r}}{\xi_{o_{s r}}}[\mathrm{~W}]
$$

where:

$v_{s r}=v=\left(v_{1}+v_{2}\right) / 2-$ the average velocity of the vessel on a particular section of track,

$p_{s i}=\left(p_{1}+p_{2}\right) / 2 \quad-$ the average value of track section,

$\xi_{o s}=$ for the power plant with slow-speed engines,

$\xi_{o s ́}=0.55$ for the power plant with high-speed engines.

In Fig. 2 is presented a standard diagram and the approximating polynomial of main engine power curve (undertow) depending on the velocity of the vessel under routine external conditions of operating.

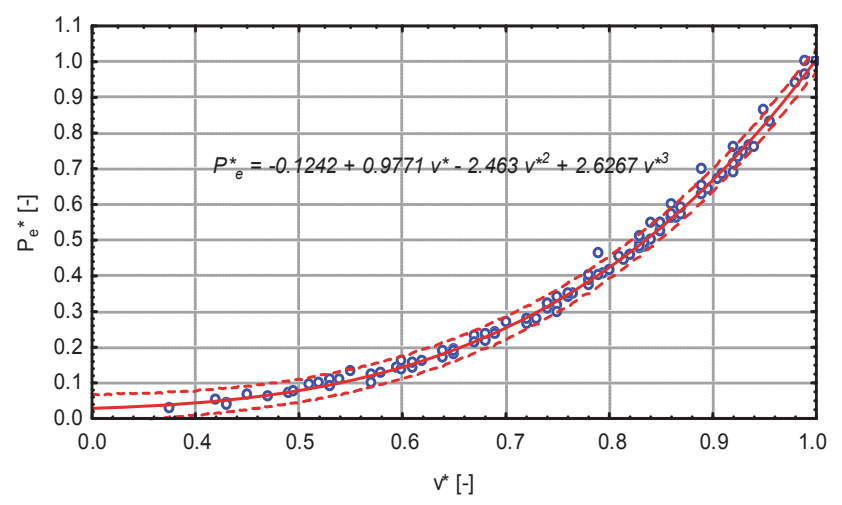

Fig. 2. Typical averaged power dependence of the main propulsion engine on the individual floating velocity of the displacement hull [4] 
It should be noted that in the presented method there is no generalized characteristics of the propeller specific emission of toxic compounds in the main engines. Determination of it is possible on the basis of experimental research on engines, both the laboratory and in the place of their permanent installation in the propulsion systems of vessels.

The averaged propulsion characteristics are also necessary to create the ecological characteristics. It is presented in Fig. 3.

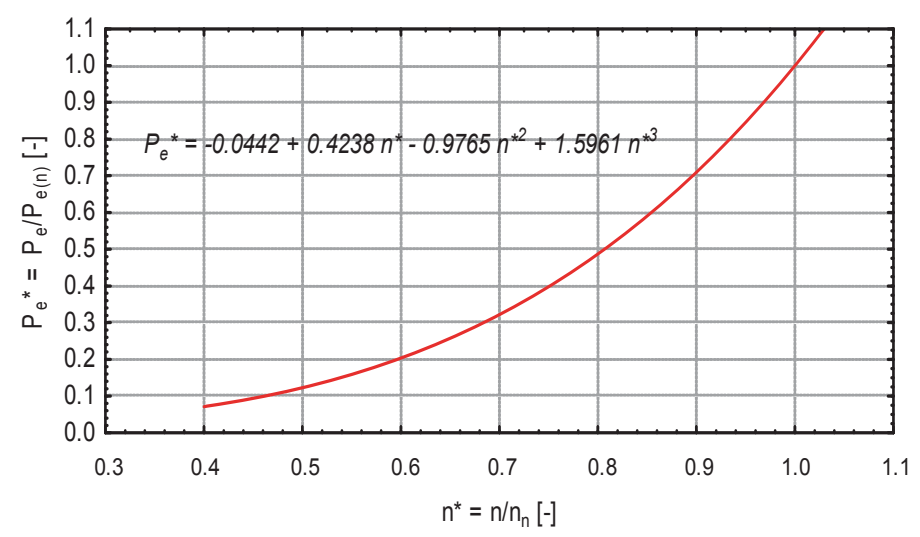

Fig. 3. Averaged characteristics of the standard main propulsion engine in the vessel with displacement hull [4]

\subsection{The ecological characteristics of the main engine}

Conditions of formation of toxic compounds in the main propulsion engine are determined by the values of load parameters (effective towing capacity $P_{e}$, vessel velocity $v$ ), thermal parameters (exhaust gas temperature $T_{s p}$, water in the cooling system $T_{w}$, oil in the lubricating system $T_{o}$ ) and parameters of air surrounding the engine (temperature $T_{a}$, pressure $p_{a}$, relative air humidity $\varphi$ ) $\bar{p}_{j}=\left(P_{e}, v, T_{s p}, T_{w}, T_{o}, T_{a}, p_{a}, \varphi\right)$. Parameters of the load and thermal status also depend on the external conditions described in the set $\bar{p}_{i}$.

On the basis of existing regulations in the considered issues, the following indicators of the toxicity of marine engines were established [2]:

- emission of the toxic compound $e_{Z T}[\mathrm{~kg} /(\mathrm{kW} \cdot \mathrm{h})]$,

- emission intensity $E_{Z T} \approx P_{e} \cdot e_{Z T}[\mathrm{~kg} / \mathrm{h}]$,

- total emission $m_{Z T}=E_{Z T} \cdot t[\mathrm{~kg}]$,

- way emission $b_{s_{Z T}}=\frac{m_{Z T}}{L_{t}}[\mathrm{~kg} / \mathrm{M}]$.

\section{Emissions of toxic compounds from tankers navigating to the Liquid Fuel Terminal in the Port of Gdansk}

The Liquid Fuel Terminal in the Port of Gdansk consists of four berths for tankers up to $350 \mathrm{~m}$ and draft to $15 \mathrm{~m}$ [11]. During the period [1], the number of tankers navigating to the Liquid Fuel Terminal accounted for 5.4\% of all individual ships at the Port of Gdansk (Fig. 4).

Based on the data obtained from the AIS System [5] it was also possible to create such length distributions (Fig. 5) and velocity of tankers (Fig. 6).

On the basis of developed by authors the mathematical model of toxic compounds in exhaust gases of main propulsion diesel engines characteristics were determined as a function of velocity $\mathrm{P}_{\mathrm{e}}=\mathrm{f}(\mathrm{v})$ of selected and most common tanker navigating to the Liquid Fuel Terminal $(\mathrm{L}=60 \mathrm{~m}, \mathrm{~B}$ $=6 \mathrm{~m}, \mathrm{~T}=4.1 \mathrm{~m}, \mathrm{v}_{\max }=12 \mathrm{kn}$ ), (Fig. 7). 


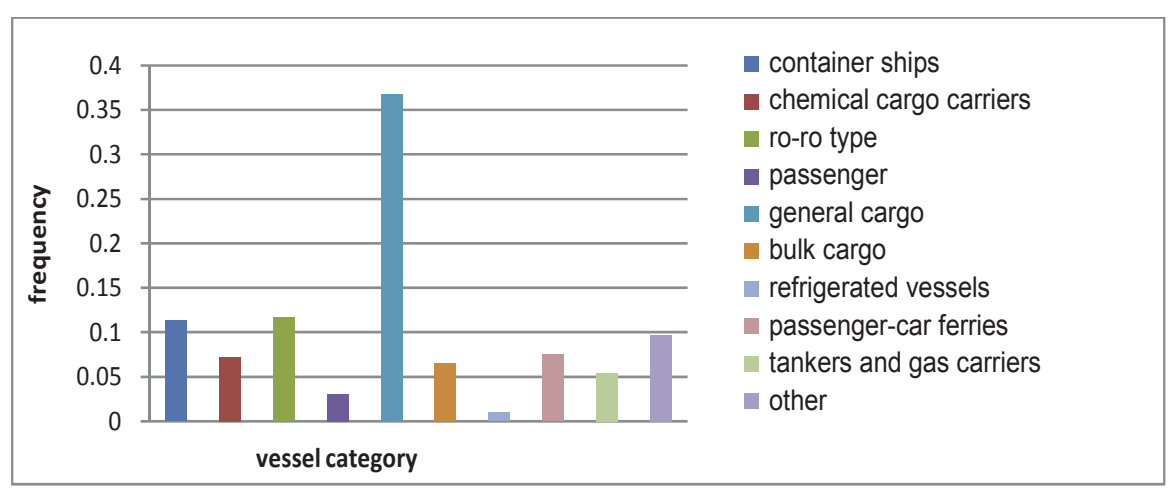

Fig. 4. Distribution of the ship occurrence in each category for the Port of Gdansk

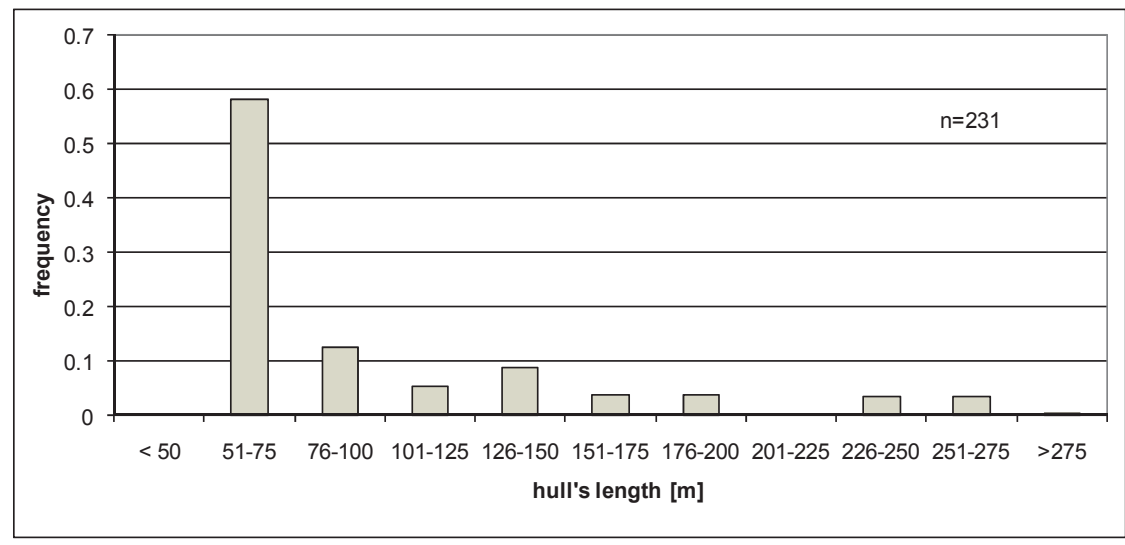

Fig. 5. Length distribution of tankers navigating to the Port of Gdansk

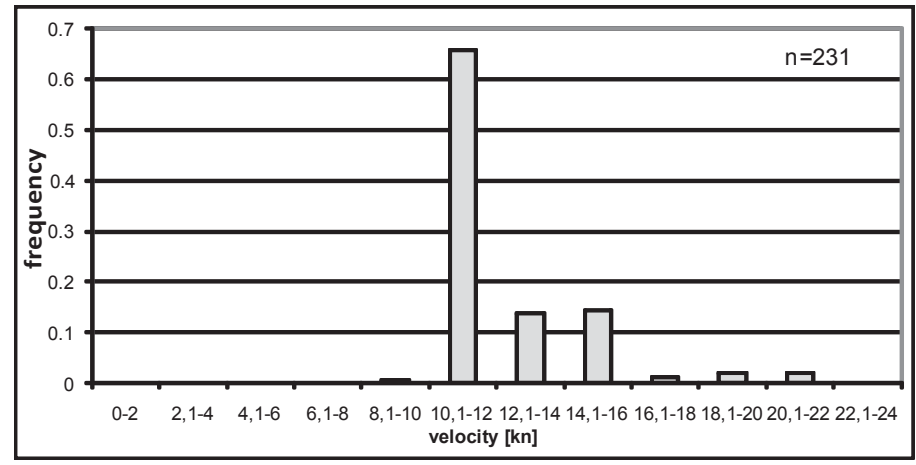

Fig. 6. Velocity distribution of tankers navigating to the Port of Gdansk

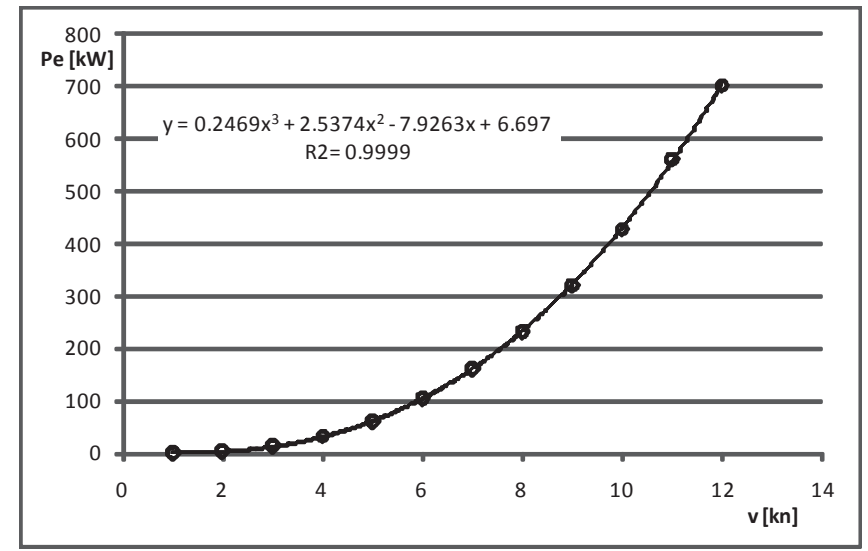

Fig. 7. Characteristics of power output as a function of velocity $P_{e}=f(v)$ of the selected tanker navigating to the Liquid Fuel Terminal ( $\left.L=60 \mathrm{~m}, B=6 \mathrm{~m}, T=4.1 \mathrm{~m}, v_{\max }=12 \mathrm{kn}\right)$ 
Because the amount of toxic compounds emitted into the atmosphere depends primarily on the engine load, subsequently on the basis of the characteristics of unit propeller emission of toxic compounds [3] it is possible to determine among others the value of intensity of emission of nitrogen oxides depending on the floating velocity of the tanker $E_{\mathrm{NOx}}=f(v)$ (Fig. 8)

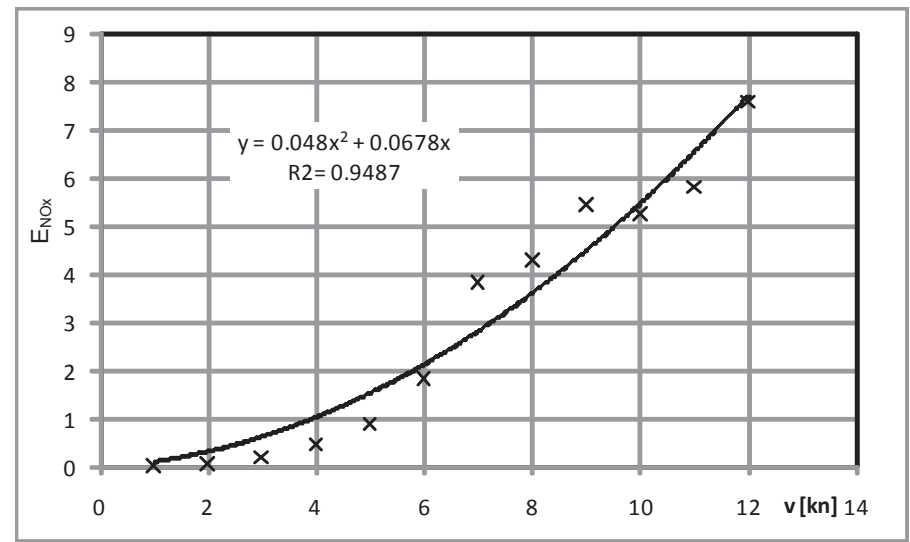

Fig. 8. Calculated dependence of the intensity of emission of nitrogen oxides from the velocity $E_{N O x}=f(v)$ of the selected tanker to the Liquid Fuel Terminal $\left(L=60 \mathrm{~m}, B=6 \mathrm{~m}, T=4.1 \mathrm{~m}, v_{\max }=12 \mathrm{kn}\right)$

\section{Summary}

The possibility to obtain data from AIS like name of ship, length and breadth of ship, type of ship, universal time related to passing through "gate", course and speed over the ground (COG and VTG) and the ship's draft, permits the creation of innovative models describing vessel traffic in the area researched and toxic compounds emission from exhausts both of a given vessel and for the whole area.

Developed model defines the course and the necessary data to determine the characteristics of the vessel and the emission of toxic compounds in the exhaust gases from marine Diesel engines of main propulsion in the basic routine conditions of operation. Developed characteristics, which define the conditions of operation of these engines are possible to apply in the tests and the characteristics of toxic compounds of other vessels. The proposed method of modelling assumes that in identifying and describing the conditions of main propulsion engines operation, the basic relation is the standard resistance characteristics (designed, normal). Based on these characteristics, subsequently it is possible to determine the characteristics of effective power and emission of toxic compounds in exhaust gases of main propulsion engines.

\section{References}

[1] Kniaziewicz, T., Piaseczny, L., Modelling the Emission and Dispersion of Toxic Compounds in Marine Engine Exhaust in the Gdansk Bay Region, Polish Journal of Environmental Studies, Vol. 18, No. 2A, pp. 76-81, 2009.

[2] Kniaziewicz, T., Piaseczny, L., Stochastic models of toxic compounds emission in exhaust from sea-going vessels sailing in a particular area, Combustion Engines, No 2009-SC1, pp. 195-203, 2009.

[3] Kniaziewicz, T., Piaseczny, L., Identyfikacja obciążenia okrętowych silników spalinowych w aspekcie oceny emisji toksycznych składników spalin, Zeszyty Naukowe AMW, Nr 4/2011 (187), Gdynia 2011.

[4] Kniaziewicz, T., Piaseczny, L., Modelling of Ecological Characteristics of Marine Main Propulsion Diesel Engines, Combustion Engines, No 3/2011 (146), pp. 99, Bielsko-Biala 2011. 
[5] Kniaziewicz, T., Piaseczny, L., Using Information from AIS System in the Modelling of Exhausts Components from Marine Main Diesel Engines, Journal of Polish CIMAC, Vol. 6, No. 1, pp. 109-117, Gdańsk 2011.

[6] Merkisz, J., Piaseczny, L., Statyczne warunki użytkowania okrętowych silników spalinowych, Logistyka, No 4/2010, pp. 20-28, 2010.

[7] Michalski, J. P., Metody przydatne do wymaganego komputerem projektowania wstepnego statków śródlądowych, Wydawnictwo Politechniki Gdańskiej, Gdańsk, 2007.

[8] Michalski, J. P., Metody wyznaczania oporu $i$ mas uogólnionych kadtuba przydatne w projektowaniu wstęnnym statków dwukadtubowych o małej wodnicy plywania, Wydawnictwo Politechniki Gdańskiej, Gdańsk 2002.

[9] Pawłowski, M., Opór okrętu, Raport Techniczny nr 58/2010, PRS, Gdańsk 2010.

[10] Wroblewskaja, L. N., Sirotina, G. N., Opriedielenije moszcznosti energiczeskoj ustanowki $w$ naczalnoj stadii projektowanija gruzowych sudow wnutrienniego i smieszanogo pławanija, Trudy GIIWT, No 144, 1975.

[11] Zarzad Morskiego Portu Gdańsk SA, http://www.portgdansk.pl/o-porcie/baza-paliwplynnych, czerwiec, 2012. 